\title{
PENGARUH EDUKASI PASAR MODAL TERHADAP PERSEPSI RISIKO DAN MINAT BERINVESTASI MASYARAKAT
}

\author{
Made Pratiwi Dewi, Ni Made Tamansari, Ni Made Santini \\ Program Studi Manajemen Fakultas Ekonomi dan Bisnis Universitas Warmadewa \\ Email: pratiwidewi_88@yahoo.com
}

\begin{abstract}
The majority of our society is not yet aware of the benefits of investing. They emphasize more importance to support life now without understanding the future. In Indonesia, based on data as of December 2018, only around 1,617,367 million were approved as independent shareholders in the Indonesian Central Securities Depository. The ratio is not even up to 0.5 percent of the total population of Indonesia. Market information and market knowledge are the main things. Today many countries agree to investment plans that want to increase domestic and international investment. This study aims to reveal the effect of capital market education on risk perceptions and community investment interests. Researchers want to look at the factors that influence the interest of investing in the community who incidentally do not have experience in investing in the stock market capital. This study uses primary data that is a questionnaire collected from participants, using a quasi-experimental technique in which participants are people who take part in voluntary capital market school activities at the Indonesian Stock Exchange KP Denpasar. The method of processing data uses path analysis. The results of this study capital market education has a positive influence on people's perceptions of interest and investment interest. While the perception does not have an interest in the interests of investing in the community.
\end{abstract}

Keywords: Investment knowledge, Investment interests, Risk perception, Capital market schools.

\section{Abstrak}

Mayoritas masyarakat kita belum menyadari manfaat dari berinvestasi. Mereka cenderung lebih mementingkan untuk menjalani hidup sekarang tanpa memikirkan masa depan. Di Indonesia, berdasarkan data per Desember 2018, tercatat hanya sekitar 1.617.367 juta penduduk yang terdaftar sebagai pemegang saham independen di Kustodian Sentral Efek Indonesia. Rasionya bahkan tidak sampai 0,5 persen dari total penduduk Indonesia. Kurangnya informasi dan pengetahuan tentang pasar modal menjadi hal utama kurang majunya pasar modal Indonesia. Sekarang ini banyak negara menerapkan kebijaksanaan yang bertujuan meningkatkan investasi baik domestik maupun modal asing. Penelitian ini bertujuan untuk mengungkap pengaruh edukasi pasar modal terhadap persepsi risiko dan minat berinvestasi masyarakat. Peneliti ingin melihat faktor-faktor yang mempengaruhi minat berinvestasi masyarakat yang notabene belum memiliki experience dalam berinvestasi saham di pasar modal. Penelitian ini menggunakan data primer yaitu kuisioner yang dikumpulkan dari partisipan, dengan menggunakan teknik kuasi eksperimen dimana partisipan adalah masyarakat yang mengikuti kegiatan sekolah pasar modal secara sukarela di Bursa Efek Indonesia KP Denpasar. Metode pengolahan data menggunakan path analysis. Hasil dari penelitian ini edukasi pasar modal memberikan pengaruh positif terhadap persepsi risiko dan minat berinvestasi masyarakat. Sedangkan persepsi risiko tidak memiliki pengaruh terhadap minat berinvestasi masyarakat.

Kata kunci: Pengetahuan investasi, Minat investasi, Persepsi Risiko, Sekolah pasar modal.

\section{PENDAHULUAN}

Investasi adalah salah satu instrumen pembangunan yang dibutuhkan oleh suatu bangsa untuk meningkatkkan kesejahteraan masyarakatnya, termasuk bangsa Indonesia. Ada dua paradigma mengenai investasi masyarakat (Mumtaz, 2010), yaitu (1) investasi dianggap sebagai sebuah keinginan, dan (2) investasi dianggap sebagai sebuah kebutuhan. Pada saat investasi dianggap sebagai sebuah keinginan, hal ini terjadi saat seseorang memiliki kelebihan uang, maka uang tersebut akan disimpan sebagai tabungan daripada digunakan untuk berinvestasi. Pemilik uang tersebut baru akan menggunakan uang tersebut untuk kepentingan investasi ketika ia memiliki minat untuk menyalurkannya ke instrumen investas. Namun ketika investasi dianggap sebagai sebuah kebutuhan, maka pada saat seseorang memiliki kelebihan uang akan langsung digunakan untuk kepentingan investasi dibandingkan untuk ditabung. Mayoritas masyarakat kita belum menyadari manfaat dari berinvestasi. Mereka cenderung lebih mementingkan untuk menjalani hidup sekarang tanpa memikirkan masa depan. Inflasi adalah salah satu faktor yang membuat seseorang membutuhkan investasi. 
Banyaknya perusahaan dapat menjadi salah satu faktor yang mendorong jumlah orang ingin berinvestasi, terutama saham di pasar modal. Data yang diperoleh dari Bursa Efek Indonesia (www.idx.co.id) per Desember 2018, tercatat 619 perusahaan yang sudah go public. Dan program terbaru yang dikeluarkan oleh Bursa Efek Indonesia sejak tahun 2015 yaitu "Yuk Nabung Saham" dan pendirian galeri investasi di Universitas-universitas di seluruh Indonesia tidak akan berpengaruh signifikan terhadap pertambahan jumlah investor, jika

\section{Gambar 1}

Grafik Pertumbuhan Total Jumlah SID (2012 - 26 Desember 2018)

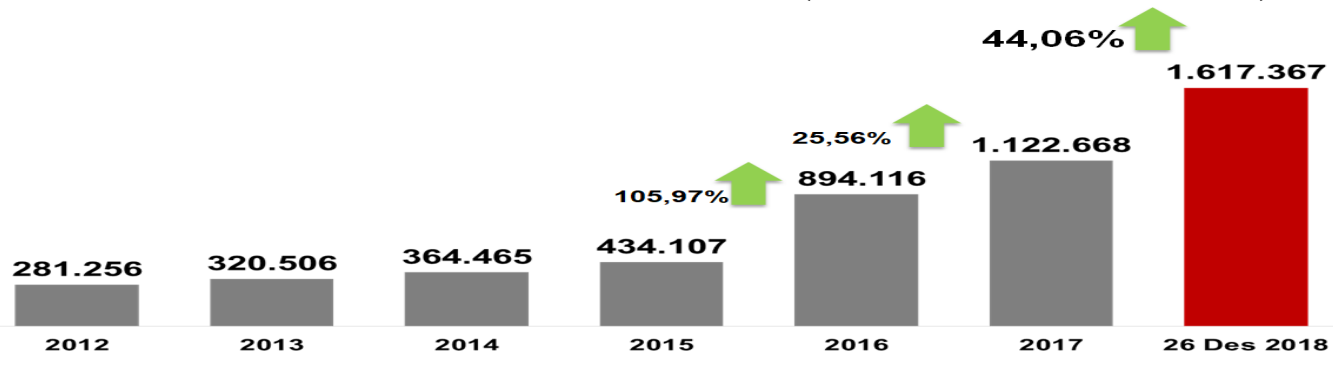

Sumber: www.ksei.co.id , 2018

\section{Gambar 2}

Sebaran Investor Domestik di Indonesia (per 26 Desember 2018)

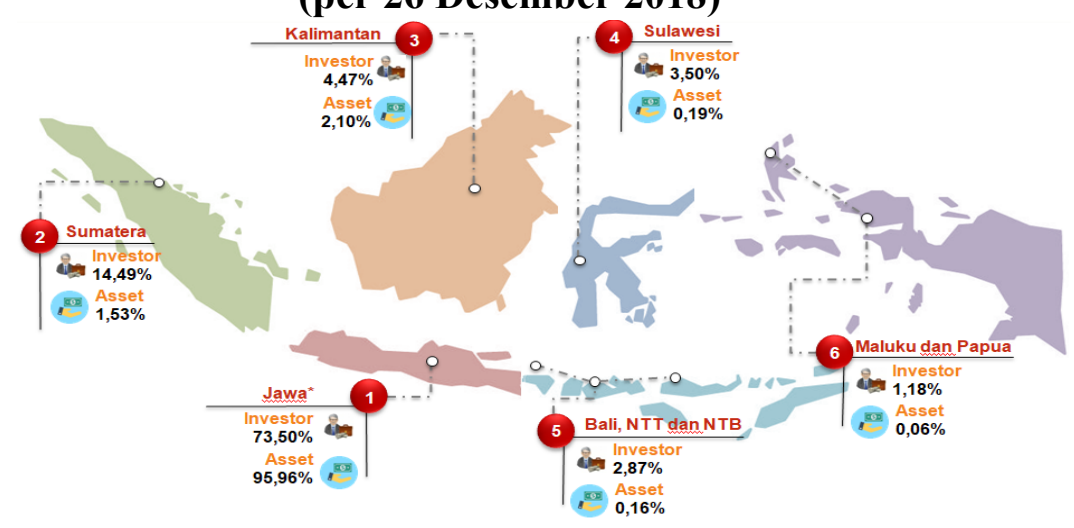

Sumber: www.ksei.co.id , 2018

Untuk sebaran investor di wilayah Indonesia yang menduduki urutan pertama yaitu di pulau Jawa $(73,50 \%)$ sedangkan urutan paling akhir adalah pulau Maluku dan Papua $(1,18 \%)$. Untuk wilayah Bali, NTT dan NTB sekitar 2,87\% dari total penduduk yang menjadi investor. Hal ini membuat timbul pertanyaan apa yang membuat begitu rendahnya minat berinvestasi masyarakat khususnya di pulau Bali dan cara apa yang perlu dilakukan agar minat tersebut dapat meningkat.

Salah satu cara untuk memberikan edukasi tentang investasi pasar modal ke generasi muda yaitu dengan program Sekolah tanpa diikuti dengan kesadaran akan investasi. Di Indonesia, berdasarkan data per Desember 2018, tercatat hanya sekitar 1.617 .367 juta penduduk yang terdaftar sebagai pemegang saham independen di Kustodian Sentral Efek Indonesia. Rasionya bahkan tidak sampai 0,5 persen dari total penduduk Indonesia. Kurangnya informasi dan pengetahuan tentang pasar modal menjadi hal utama kurang majunya pasar modal Indonesia, seperti yang terlihat pada Gambar 1. 
besar return yang harus dikompensasikan (Jogiyanto, 2010).

Berbagai macam faktor dapat mempengaruhi minat seseorang dalam berinvestasi, baik faktor eksternal seperti pelatihan pasar modal dengan mengikuti Sekolah Pasar Modal (SPM) maupun faktor internal seperti persepsi mengenai risiko. Penelitian yang menguji hubungan faktorfaktor tersbut terhadap kepemilikan saham banyak ditemukan di luar negeri (Shum \& Faig, 2005; Cardak \& Wilkins, 2009; Yamishita, 2003). Oleh karena itu, penelitian ini dilakukan untuk mengevaluasi pengaruh Edukasi Pasar Modal terhadap persepsi risiko dan minat berinvestasi masyarakat. Penelitian ini dilakukan di Bursa Efek Indonesia KP Denpasar dengan mengajak masyarakat setempat yang mau ikut secara sukarela untuk mengikuti Sekolah Pasar Modal sehingga dapat diketahui bagaimana pengaruh terhadap persepsi risiko dan minat berinvestasi masyarakat di pasar modal. Masyarakat sebagai partisipan nantinya setelah selesai mengikuti Sekolah Pasar Modal akan diberikan kuisioner terkait dengan variabel penelitian. Pengujian dari hasil kuisioner tersebut akan diuji dengan mengunakan path analysis, sehingga dapat diketahui apakah persepsi risiko akan memperlemah atau memperkuat pengaruh dari edukasi pasar modal terhadap minat berinvestasi.

\section{TINJAUAN PUSTAKA}

\section{Theory of Planned Behavior / Theory of Reasoned Action}

Pada Theory of Planned Behavior ini juga dijelaskan bahwa niat berperilaku (behavioral intention) tidak hanya dipengaruhi oleh sikap terhadap perilaku (attitude towards behavior) dan norma subyektif (subjective norm), tetapi juga dipengaruhi oleh kontrol keperilakuan yang dirasakan (perceived behavioral control). Kontrol keperilakuan dipengaruhi oleh pengalaman masa lalu dan perkiraan seseorang mengenai sulit atau tidaknya untuk melakukan perilaku tertentu (Azwar, 2003). Karenanya niat berperilaku dapat menunjukkan perilaku yang akan dilakukan oleh seseorang. Hal ini dapat menjelaskan apabila seorang yang memiliki minat berinvestasi di pasar modal maka dia akan cenderung melakukan tindakan-tindakan untuk dapat mencapai keinginannya berinvestasi. Misalkan saja dengan mengikuti pelatihan dan seminar tentang investasi di pasar modal, menerima dengan baik penawaran investasi di pasar modal, dan pada akhirnya melakukan investasi di pasar modal.

\section{Minat Investasi di Pasar Modal}

Menurut Winkel (1983), minat merupakan kecenderungan yang menetap dalam subjek untuk merasa senang dan tertarik pada bidang atau hal tertentu dan merasa senang berkecimpung dalam bidang itu, sedangkan menurut Hurlock (1999), minat seseorang dapat ditumbuhkan dengan memberikan kesempatan bagi orang tersebut untuk belajar mengenai hal yang dia inginkan. Minat menurut Stiggins (1994) adalah salah satu dimensi dalam aspek afektif yang memiliki peran besar dalam kehidupan seseorang. Dimensi afektif ini mencakup beberapa hal diantaranya yaitu: 1) berhubungan dengan perasaan mengenai obyek berbeda, 2) perasaanperasaan tersebut memiliki arah yang dimulai dari titik netral ke titik yang berlawanan, tidak positif dan tidak negatif, 3 ) berbagai perasaan yang memiliki intensitas berbeda, dari lemah, sedang, hingga kuat. Widyastuti, dkk (2004) minat merupakan keinginan yang didorong oleh suatu keinginan setelah melihat, mengamati dan membandingkan serta mempertimbangkan dengan kebutuhan yang diinginkannya. Minat menunjukkan seberapa banyak upaya yang direncanakan seseorang untuk melakukan sesuatu (Tengker dan Morasa, 2007). Dari definisi-definisi tersebut, maka dapat disimpulkan bahwa minat merupakan salah satu dari dimensi dalam aspek afektif yang dapat menyebabkan seseorang memiliki intensitas atau kecenderungan kesukaan yang berbeda anatara suatu kegiatan dengan kegiatan lainnya setelah melihat, mengamati dan membandingkan serta mempertimbangkan dengan kebutuhannya disertai dengan upaya yang direncanakan dan perasaan senang.

\section{Persepsi Risiko}

Persepsi adalah bagaimana cara seseorang melihat dan menginterpretasikan suatu keadaan atau peristiwa, sebagian besar seseorang akan bertindak berdasarkan pada persepsi dan mengabaikan pada kenyataan yang sebenarnya (Lubis, 2010). Jadi persepsi risiko merupakan cara pandang seseorang dalam menilai kerugian yang akan dialami dalam melakukan investasi. Untuk itu dalam berinvestasi seorang investor tidak boleh 
mengambil keputusan hanya berdasarkan pada persepsi orang lain tetapi harus berdasarkan analisis yang benar - benar tepat agar terhindar dari risiko kerugian yang tinggi. Yuwono (2011) menemukan persepsi terhadap risiko adalah salah satu faktor yang paling memengaruhi minat investasi. Risiko dalam konteks portofolio (diversifikasi) menurut Halim (2005) dapat dibedakan menjadi dua, yaitu : Risiko sistematis (systematic risk) merupakan risiko yang tidak dapat dihilangkan dengan melakukan diversifikasi, karena fluktuasi risiko ini dipengaruhi oleh faktorfaktor makro yang dapat mempengaruhi pasar secara keseluruhan. Risiko tidak sistematis (unsystematic risk) merupakan risiko yang dapat dihilangkan dengan melakukan diversifikasi, karena risiko ini hanya ada dalam satu perusahaan atau industri tertentu.

\section{Edukasi Pasar Modal}

Edukasi pasar modal adalah memberikan pengetahuan dasar tentang invetasi di pasar modal. Pengetahuan investasi adalah pengetahuan dasar yang dimiliki untuk melakukan investasi. Ukuran variabel yang digunakan untuk pengetahuan investasi adalah pemahaman tentang kondisi berinvestasi dan pengetahuan dasar penilaian saham. Pengetahuan akan hal tersebut akan memudahkan seseorang untuk mengambil keputusan berinvestasi, karena pengetahuan merupakan dasar pembentukan sebuah kekuatan bagi seseorang untuk mampu melakukan sesuatu yang diinginkannya (Efferin, 2006). Hal ini sebagaimana yang diungkapkan oleh Halim (2005) bahwa untuk melakukan investasi di pasar modal diperlukan pengetahuan yang cukup, pengalaman serta naluri bisnis untuk menganalisis efek-efek mana yang akan dibeli. Pengetahuan yang memadai sangat diperlukan untuk menghindari terjadinya kerugian saat berinvestasi di pasar modal, seperti pada instrumen investasi saham.

\section{Pengaruh Edukasi Pasar Modal terhadap Persepsi Risiko}

Edukasi pasar modal adalah memberikan pengetahuan dasar tentang invetasi di pasar modal. Pengetahuan akan hal tersebut akan memudahkan seseorang untuk mengambil keputusan berinvestasi, karena pengetahuan merupakan dasar pembentukan sebuah kekuatan bagi seseorang untuk mampu melakukan sesuatu yang diinginkannya
(Efferin, 2006). Halim (2005) mengungkapkan bahwa untuk melakukan investasi di pasar modal diperlukan pengetahuan yang cukup, pengalaman serta naluri bisnis untuk menganalisis efek-efek mana yang akan dibeli. Pengetahuan yang memadai sangat diperlukan untuk menghindari terjadinya kerugian saat berinvestasi di pasar modal, seperti pada instrumen investasi saham.

H1 : Edukasi Pasar Modal berpengaruh positif dan signifikan terhadap Persepsi Risiko

\section{Pengaruh Edukasi Pasar Modal terhadap Minat Berinvestasi}

Menurut Dahan (2011) pembelajaran merupakan hasil dari pengalaman. Banyak pengalaman yang didapatkan setelah mengikuti pelatihan pasar modal yang bisa dijadikan sebagai bahan pembelajaran dan bisa menumbuhkan minat berinvestasi. Tandio dan Widanaputra (2016) mengemukakan bahwa pelatihan pasar modal merupakan bentuk pembelajaran bagi individu mengenai pasar modal yang kemudian akan menumbuhkan minat bagi individu tersebut.

H2 : Edukasi Pasar Modal berpengaruh positif dan signifikan terhadap Minat Berinvestasi.

\section{Pengaruh Persepsi Risiko terhadap Minat Berinvestasi}

Investasi di pasar modal tidak dapat dipisahkan antara return dan tingkat risiko karena semakin tinggi return yang akan diperoleh (high risk return) dalam investasi maka risiko yang dihadapi juga akan semakin tinggi (Sharpe dkk, 2005). Persepsi risiko merupakan cara pandang seseorang dalam menilai kerugian yang akan dialami dalam melakukan investasi.

H3 : Persepsi Risiko berpengaruh positif dan signifikan terhadap Minat Berinvestasi.

\section{METODE PENELITIAN}

Penelitian ini dilakukan di Bursa Efek Indonesia KP Denpasar yang bertempat di Jalan Cok Agung Tresna, Renon. Yang menjadi objek penelitian adalah masyarakat di Denpasar yang dengan sukarela mengikuti sekolah pasar modal untuk edukasi pengetahuan tentang pasar modal, persepsi terhadap risiko, dan minat berinvestasi di pasar modal terutama pada instrumen saham. Penelitian ini menggunakan data primer yaitu data kuisioner yang 
dikumpulkan dari partisipan, dengan menggunakan teknik kuasi eksperimen dimana partisipan adalah 100 orang yang bersedia mengikuti sekolah pasar modal yang dilaksanakan oleh Bursa Efek Indonesia KP Denpasar untuk mengetahui persepsi terhadap risiko dan minat berinvestasi.

\section{Tabel 1}

Definisi Operasional Variabel Penelitian

\begin{tabular}{|c|c|c|c|}
\hline Variabel & INDIKATOR & INSTRUMEN & SUMBER \\
\hline \multirow{2}{*}{$\begin{array}{l}\text { Edukasi Pasar } \\
\text { Modal (X) }\end{array}$} & $\begin{array}{l}\text { Pengetahuan dasar } \\
\text { penilaian saham }\end{array}$ & $\begin{array}{l}\text { 1. Sebagai calon investor, pengetahuan dasar } \\
\text { tentang investasi sangat penting } \\
\text { 2. Sekolah pasar modal membantu investor untuk } \\
\text { menambah pengetahuan investasi } \\
\text { 3. Pemahaman tentang pengetahuan dasar investasi } \\
\text { wajib dikuasai sebelum melakukan investasi }\end{array}$ & \multirow{2}{*}{$\begin{array}{l}\text { Kusmawati } \\
\text { (2011) }\end{array}$} \\
\hline & $\begin{array}{l}\text { Pengetahuan } \\
\text { pemgembalian } \\
\text { investasi }\end{array}$ & $\begin{array}{l}\text { 4. Saya menanamkan investasi pada perusahaan } \\
\text { yang memberikan return cukup tinggi } \\
\text { 5. Saya melakukan analisis perhitungan sebelum } \\
\text { memilih perusahaan untuk diinvestasikan } \\
\text { 6. Saya menanamkan investasi dengan harapan } \\
\text { mendapatkan keuntungan }\end{array}$ & \\
\hline \multirow{3}{*}{$\begin{array}{c}\text { Minat } \\
\text { Berinvetasi (Z) }\end{array}$} & $\begin{array}{l}\text { Keinginan untuk } \\
\text { mencari tahu } \\
\text { tentang jenis suatu } \\
\text { invetasi }\end{array}$ & $\begin{array}{l}\text { 1. Saya membaca buku panduan langkah-langkah } \\
\text { berinvestasi sebelum memulai investasi } \\
\text { 2. Saya melihat berita mengenai investasi di } \\
\text { berbagai media sebagai bahan pertimbangan } \\
\text { pengambilan keputusan } \\
\text { 3. Sebelum saya berinvestasi, saya mencari tahu } \\
\text { terlebih dahulu informasi mengenai kelebihan } \\
\text { dan kekurangan dari jenis investasi yang akan } \\
\text { saya ambil }\end{array}$ & \multirow{3}{*}{$\begin{array}{l}\text { Kusmawati } \\
\text { (2011) }\end{array}$} \\
\hline & $\begin{array}{l}\text { Mau meluangkan } \\
\text { waktu untuk } \\
\text { mempelajari lebih } \\
\text { jauh tentang } \\
\text { investasi }\end{array}$ & $\begin{array}{l}\text { 4. Mengikuti pelatihan atau seminar investasi } \\
\text { merupakan cara sata dalam meluangkan waktu } \\
\text { untuk meningkatkan motivasi berinvestasi } \\
\text { 5. Membaca artikel mengenai investasi merupakan } \\
\text { cara saya meluangkan waktu untuk } \\
\text { meningkatkan motivasi berinvestasi } \\
\end{array}$ & \\
\hline & $\begin{array}{l}\text { Serta mencoba } \\
\text { berinvestasi }\end{array}$ & $\begin{array}{ll}\text { 6. } & \text { Tokoh inspirasi seperti Warren Buffet membuat } \\
\text { saya berkeingginan untuk mencoba berinvestasi } \\
\text { 7. } \\
\text { Ketentuan modal minimal Rp. 100.000,- untuk } \\
\text { membuka account di beberapa perusahaan } \\
\text { sekuritas membuat saya berminat untuk } \\
\text { berinvestasi } \\
\text { 8. } \begin{array}{l}\text { Saya tertarik berinvestasi di pasar modal karena } \\
\text { berbagai informasi mearik mengenai kelebihan } \\
\text { dari jenis investasi yang di tawarkan }\end{array}\end{array}$ & \\
\hline \multirow[t]{2}{*}{$\begin{array}{l}\text { Persepsi Risiko } \\
\text { (Y) }\end{array}$} & Tingkat Risiko & $\begin{array}{l}\text { 1. Mengukur Risiko membatu investor dalam } \\
\text { meminimalisir terjadinya kerugian } \\
\text { 2. Besarnya keuntungan yang diperoleh sebanding } \\
\text { dengan risiko yang akan ditanggung } \\
\text { 3. Saya memilih investasi dengan tingkat risiko } \\
\text { rendah } \\
\text { 4. Investasi dengan tingkat risiko tinggi namun } \\
\text { return nya juga tinggi merupakan tantangan } \\
\text { menarik bagi saya }\end{array}$ & \multirow[t]{2}{*}{$\begin{array}{l}\text { Kusmawati } \\
\text { (2011), } \\
\text { Oktiana } \\
(2018)\end{array}$} \\
\hline & Psikological Risk & $\begin{array}{l}\text { 5. Kerugian yang saya derita akibat investasi } \\
\text { membuat saya frustasi dan putus asa } \\
\text { 6. Investasi di pasar modal akan banyak menyita } \\
\text { waktu }\end{array}$ & \\
\hline
\end{tabular}

Teknik analisis data yang digunakan adalah Analisis Jalur (Path Analysis). Teknik analis jalur ini akan digunakan dalam menguji besarnya sumbangan (kontribusi) yang ditunjukan oleh koefisien jalur pada setiap diagram jalur dari hubungan kausal antar variable $\mathrm{X}_{1}, \mathrm{X}_{2}$, dan $\mathrm{X}_{3}$, terhadap $\mathrm{Y}$ serta dampaknya terhadap Z. Analisis korelasi dan regresi yang merupakan dasar dari perhitungan 
koefisien jalur. Kemudian dalam perhitunngan digunakan jasa komputer

berupa software dengan program SPSS. (Ridwan dan Engkos, 2008).

Gambar 3

Diagram Jalur Mengenai Hubungan Edukasi Pasar Modal, Persepsi Risiko dan Minat Berinvestasi

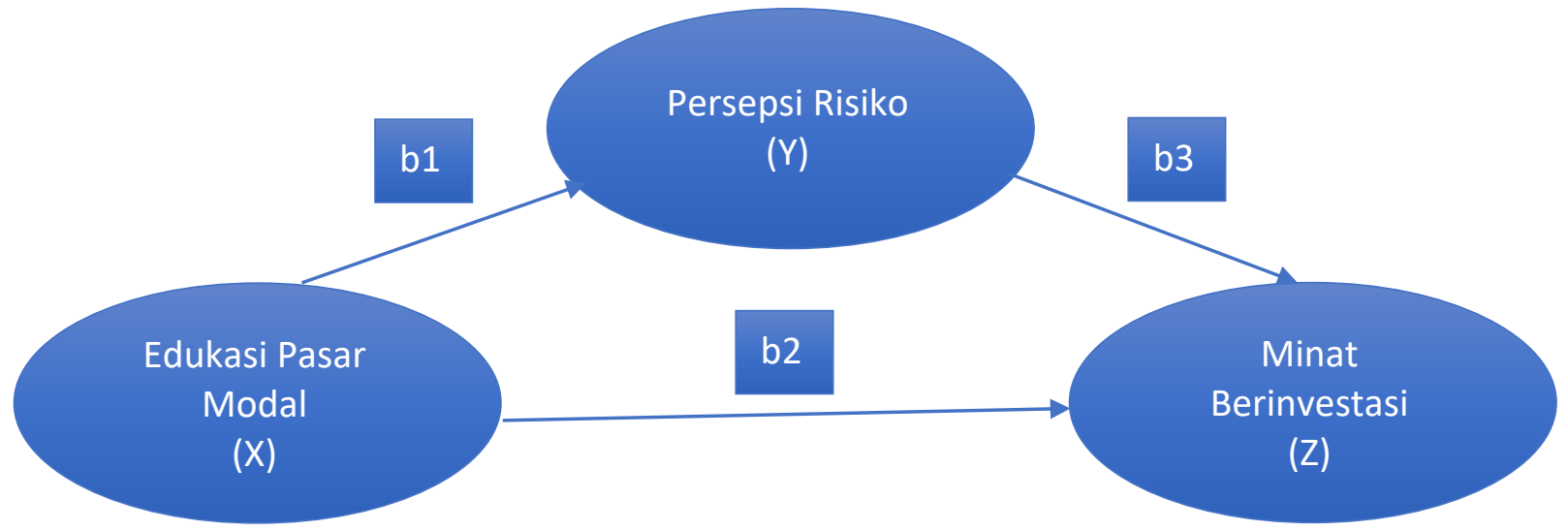

Sumber: Data diolah, 2019

\section{HASIL PENELITIAN DAN PEMBAHASAN}

Hasil Uji Sub Struktur I dan Sub Struktur II

Tabel 2

Hasil Uji Sub Struktur I dan Hasil Uji Sub Struktur II Pengaruh Edukasi Pasar Modal, Persepsi Risiko, serta Minat Berinvestasi

\begin{tabular}{|c|l|l|l|l|l|}
\hline Hubungan & $\begin{array}{c}\text { Standardized } \\
\text { Coefficients }\end{array}$ & $\begin{array}{c}\text { Standar } \\
\text { Eror (SE) }\end{array}$ & \multicolumn{1}{|c|}{ t } & P. Value/Sig & Keterangan \\
\hline $\mathrm{X} \rightarrow \mathrm{Y}$ & 0,396 & 0,079 & 4,269 & 0,000 & Signifikan \\
\hline $\mathrm{X} \rightarrow \mathrm{Z}$ & 0,434 & 0,126 & 4,492 & 0,000 & Signifikan \\
\hline $\mathrm{Y} \rightarrow \mathrm{Z}$ & 0,109 & 0,148 & 1,128 & 0,281 & $\begin{array}{l}\text { Tidak } \\
\text { Signifikan }\end{array}$ \\
\hline
\end{tabular}

Sumber: Data diolah (2019), Lampiran 1

Keterangan:

$\mathrm{X}=$ Edukasi pasar modal

$\mathrm{Y} \quad=$ Persepsi risiko

$\mathrm{Z}=$ Minat berinvestasi

$\alpha \quad=5 \%$ atau 0,05

P.value $\leq \alpha=$ signifikan dan P.value $>\alpha=$ tidak signifikan
Tabel 2 dapat dijelaskan terdapat dua jalur yang menunjukan pengaruh signifikan yaitu Edukasi pasar modal terhadap persepsi risiko dan Edukasi pasar modal terhadap minat berinvestasi. Sedangkan satu jalur memiliki pengaruh tidak signifikan yaitu persepsi risiko terhadap minat berinvestasi.

\section{Analisis Efek Langsung, Efek Tidak Langsung dan Efek Total}

\section{Tabel 3}

Pengaruh Langsung, Pengaruh Tidak Langsung, dan Pengaruh Total Edukasi Pasar Modal, Persepsi Risiko dan Minat Berinvestasi

\begin{tabular}{|l|l|l|}
\hline Tipe Pengaruh & Variabel & Standardized Coefficients \\
\hline Pengaruh Langsung & $\begin{array}{l}\text { Edukasi pasar modal }(\mathrm{X}) \rightarrow \\
\text { Persepsi risiko (Y) } \\
\text { Edukasi pasar modal }(\mathrm{X}) \rightarrow\end{array}$ & $0,396\left(\mathrm{~b}_{1}\right)$ \\
& $\begin{array}{l}\text { Minat berinvestasi }(\mathrm{Z}) \\
\left(\mathrm{b}_{2}\right)\end{array}$ & $0,109\left(\mathrm{~b}_{3}\right)$ \\
\hline
\end{tabular}




\begin{tabular}{|l|l|l|}
\hline & $\begin{array}{l}\text { Persepsi risiko }(Y) \rightarrow \text { Minat } \\
\text { berinvestasi }(\mathrm{Z})\end{array}$ & \\
\hline Pengaruh Tidak Langsung & $\begin{array}{l}\text { Edukasi pasar modal }(\mathrm{X}) \rightarrow \\
\text { Minat berinvestasi }(\mathrm{Z})\end{array}$ & $(0,396 \times 0,109)=0,043$ \\
\hline Pengaruh Total & $\begin{array}{l}\text { Edukasi pasar modal }(\mathrm{X}) \rightarrow \\
\text { Minat berinvestasi }(\mathrm{Z})\end{array}$ & $0,434+0,043=0,477$ \\
\hline
\end{tabular}

Sumber: Data diolah (2019)

Berdasarkan Tabel 3 diatas dapat diketahui bahwa pengaruh langsung, pengaruh tidak langsung, dan pengaruh total Edukasi pasar modal (X) terhadap Minat berinvestasi (Z). Pengaruh langsung dari masing-masing variabel yaitu Edukasi pasar modal (X) terhadap Persepsi risiko (Y) adalah 0,396 yang menunjukan pengaruh positif. Pengaruh langsung variabel Edukasi pasar modal (X) terhadap Minat berinvestasi (Z) adalah 0,434 yang menunjukan pengaruh positif. Pengaruh langsung variabel Persepsi risiko (Y) terhadap Minat berinvestasi ( $Z$ ) adalah 0,109 yang menunjukan pengaruh positif.

Pengaruh tidak langsung variabel Edukasi pasar modal (X) terhadap Minat berinvestasi ( $\mathrm{Z}$ ) diperoleh dari $\left(b_{1} \times b_{3}\right)$ yaitu $(0,396 \times 0,109)=$ 0,043 . Pengaruh total variabel Edukasi pasar modal $(\mathrm{X})$ terhadap Minat berinvestasi (Z) sebesar $0,434+0,043=0,477$.

\section{Pembahasan \\ Pengaruh Edukasi Pasar Modal terhadap Persepsi Risiko}

Edukasi pasar modal berpengaruh positif dan signifikan terhadap persepsi risiko. Edukasi pasar modal dalam penelitian ini diberikan kepada partisipan melalui pelaksanaan Sekolah Pasar Modal yang dilakukan di Bursa Efek Indonesia KP Denpasar dan bekerja sama dengan pihak BNI Sekuritas. Edukasi pasar modal yang diberikan adalah pengetahuan dasar tentang invetasi di pasar modal. Pengetahuan akan hal tersebut akan memudahkan seseorang untuk mengambil keputusan berinvestasi, karena pengetahuan merupakan dasar pembentukan sebuah kekuatan bagi seseorang untuk mampu melakukan sesuatu yang diinginkannya (Efferin, 2006). Hal ini sebagaimana yang diungkapkan oleh Halim (2005) bahwa untuk melakukan investasi di pasar modal diperlukan pengetahuan yang cukup, pengalaman serta naluri bisnis untuk menganalisis efek-efek mana yang akan dibeli. Pengetahuan yang memadai sangat diperlukan untuk menghindari terjadinya kerugian saat berinvestasi di pasar modal, seperti pada instrumen investasi saham. Perlu disadari bahwa dalam berinvestasi di pasar modal ada pedoman tentang risiko yang harus dipahami oleh investor yaitu high risk high return, semakin tinggi investor menginginkan keuntungan maka semakin tinggi risiko yang dihadapi. Risiko tidak dapat dihilangkan tapi dapat diminimalisir dengan adanya pemahaman tentang pengetahuan berinvestasi. Sehingga semakin seorang investor memiliki pemahaman tentang pengetahuan berinvestasi maka semakin positif persepsinya terhadap risiko. Hal ini dapat dilihat dari sebagian besar partisipan memiliki lebih dari 1 instrumen investasi yang mana partisipan sudah melakukan diversifikasi untuk risiko berinvestasi.

\section{Pengaruh Edukasi Pasar Modal terhadap Minat Berinvestasi}

Edukasi pasar modal berpengaruh positif signifikan terhadap minat berinvestasi. Sebagian besar masyarakat sudah sering mendengar investasi, khususnya yang bertemakan tentang keuangan, namun tidak semua mengetahui cara berinvestasi di pasar modal. Investasi merupakan suatu hal yang penting untuk menjaga nilai uang sehingga bisa mengurangi ancaman inflasi. Karena kurangnya pengetahuan investor terhadap cara berinvestasi yang benar, sehingga banyak investor mengalami kegagalan dalam investasinya dan membuat pandangan bahwa investasi di pasar modal memiliki risiko yang tinggi. Pelatihan mengenai pasar modal sangat penting diketahui sebelum investor masuk kedalam lantai bursa. Pelatihan mengenai pasar modal baik dari matakuliah yang diberikan, seminar-seminar dan keikutsertaan dalam sekolah pasar modal merupakan bentuk pembelajaran bagi individu yang terlibat yang kemudian akan menumbuhkan minat bagi individu tersebut. Menurut Dahan (2011) pembelajaran merupakan hasil dari pengalaman. Banyak pengalaman yang didapatkan partisipan setelah mengikuti pelatihan pasar modal yang bisa dijadikan sebagai bahan pembelajaran dan bisa 
menumbuhkan minat berinvestasi yang dapat terlihat partisipan mau membuka rekening dana nasabah (RDN) di BNI Sekuritas serta mau memulai berinvestasi saham. Tandio dan Widanaputra (2016) mengemukakan bahwa pelatihan pasar modal merupakan bentuk pembelajaran bagi individu mengenai pasar modal yang kemudian akan menumbuhkan minat bagi individu tersebut.

\section{Pengaruh Persepsi Risiko terhadap Minat Berinvestasi}

Persepsi risiko berpengaruh positif dan tidak signifikan terhadap minat berinvestasi. Persepsi adalah bagaimana cara seseorang melihat dan menginterpretasikan suatu keadaan atau peristiwa, sebagian besar seseorang akan bertindak berdasarkan pada persepsi dan mengabaikan pada kenyataan yang sebenarnya (Lubis, 2010). Jadi persepsi risiko merupakan cara pandang seseorang dalam menilai kerugian yang akan dialami dalam melakukan investasi. Untuk itu dalam berinvestasi seorang investor tidak boleh mengambil keputusan hanya berdasarkan pada persepsi orang lain tetapi harus berdasarkan analisis yang benar - benar tepat agar terhindar dari risiko kerugian yang tinggi. Dilansir dari www.logikabisnis.com mengenai prihal-prihal yang harus di pahami dan dipertimbangkan seseorang sebelum berinvestasi diantaranya yakni memahami cara kerja dan tujuan bisnis/investasi, memahami risiko dan return yang diperoleh, mempelajari tentang bisnis perusahaan tempat berinvestasi, memilih perusahaan yang memiliki fundamental bisnis yang kuat, jangka waktu berinvestasi, mengalokasikan portofolio secara efsien, mempelajari tentang analisis saham baik teknikal maupun fundamental, bersikap tidak terlalu agresif sehingga perlu adanya defensif, disiplin dan jangan serakah. Dalam penelitian ini partisipan hanya diberikan satu kali pelatihan dan disarankan untuk langsung melakukan investasi di pasar modal, sehingga belum dapat memperlihatkan persepsi yang positif akan risiko di pasar modal. Hal tersebut dapat dilihat dalam jawaban kuisioner yang disebarkan masih ada partisipan yang frustasi dan putus asa apabila megalami kerugian akibat berinvestasi serta menggangap bahwa investasi di pasar modal menyita banyak waktu. Pada dasarnya tidak ada seorang pun yang menyukai risiko. Perbedaannya hanya pada seberapa besar setiap orang mampu menerima risiko. Ada yang hanya mampu menerima risiko rendah, namun ada juga yang mampu atau siap menanggung risiko yang tinggi. Dalam penelitian ini latar belakang pendidikan, pekerjaan, serta usia dari partisipan menjadikan persepsi risiko yang terbentuk dari masingmasing partisipan berbeda-beda. Hasil penelitian ini didukung oleh penelitian yang dilakukan oleh Tandio dan Widanaputra (2016) menunjukkan hasil variabel persepsi risiko tidak mempengaruhi minat berinvestasi mahasiswa.

\section{Pengaruh Edukasi Pasar Modal terhadap Minat Berinvestasi dengan Persepsi Risiko sebagai Variabel Intervening}

Edukasi pasar modal berpengaruh positif dan signifikan terhadap persepsi risiko yang berarti bahwa hipotesis 1 diterima. Semakin memiliki pengetahuan tentang investasi pasar modal membuat partisipan memiliki persepsi yang positif terhadap risiko. Edukasi pasar modal berpengaruh positif terhadap minat berinvestasi berarti bahwa hipotesis 2 diterima. Edukasi pasar modal merupakan bentuk pembelajaran bagi masyarakat mengenai pasar modal yang kemudian akan menumbuhkan minat berinvestasi bagi masyarakat. Hasil penelitian tidak langsung edukasi pasar modal terhadap minat berinvestasi melalui persepsi risiko memiliki arah yang positif tapi tidak signifikan, sehingga dalam penelitian ini persepsi risiko tidak terbukti peranannya sebagai variabel intervening. Seperti yang sudah dijelaskan sebelumnya edukasi pasar modal yang diberikan dalam penelitian ini hanya satu kali saja dan latar belakang pendidikan, pekerjaan, serta rentang usia yang berbeda dari partisipan menyebabkan terbentuknya persepsi risiko yang berbeda-beda.

\section{SIMPULAN DAN SARAN}

Berdasarkan hasil dan pembahasan diatas, maka penulis dapat mengambil kesimpulan sebagai berikut:

1. Edukasi pasar modal berpengaruh positif terhadap persepsi risiko.

2. Edukasi pasar modal berpengaruh positif terhadap minat berinvestasi masyarakat.

3. Persepsi risiko tidak memiliki pengaruh terhadap minat berinvestasi.

Walaupun penelitian ini telah menghasilkan temuan awal terhadap hubungan dari edukasi pasar modal, persepsi risiko dan minat berinvestasi yang mana hasil dari persepsi risiko yang tidak memliki pengaruh 
terhadap minat berinvestasi masyarakat masih bertentangan dengan teori dan beberapa hasil penelitian terdahulu. Sehingga untuk penelitian selanjutnya perlu dilakukan pemilihan responden yang tidak terlalu random, waktu untuk melakukan edukasi yang lebih lama agar penyampaian materi-materi lebih detail serta untuk penelitian lebih lanjut dengan memasukan faktor-faktor lain seperti persepsi akan return, self efficacy, dan lainnya. Bagi lembaga Universitas Warmadewa dan Fakultas Ekonomi dan Bisnis Unwar dapat melaksanakan Sekolah Pasar Modal secara mandiri melalui Galeri Investasi BEI Unwar.

\section{DAFTAR PUSTAKA}

Ajzen, I. 1985. From intentions to actions: A theory of planned behavior. In J. Kuhl \& J. Beckman (Eds.).

Barber, B.M., Terrance Odean. 2011. The Behavior of Individual Investors. Quarterly Journal of Economics.

Barnea, Amir., et al. 2010. Nature or Nurture: What Determines Investor Behavior?

Bartlett, J. E. II; Kotrlik, J.W., \& Higgins, C. 2001. Organizational research: Determining appropriate sample size for survey research. Information Technology, Learning, and Performance Journal.

Benzoni, L., Olena Chyruk. 2009. Investing over the life cycle with long-run labor income risk. Federal Reserve Bank of Chicago. Economic Perspectives Journal, 29-43.

Cardak, B. A. \& Wilkins, R. 2009. The Determinants of Households Risky Asset Holdings: Australian Evidence On Background Risk and Other Factors. Journal of Banking and Finance, 33, 850-860.

Ghozali, Imam. 2016. Aplikasi Analisis Multivariate dengan Program SPSS, Edisi ke-4, Bagian Penerbit Universitas Diponegoro. Semarang.

Halim, Abdul. 2005. Analisis Investasi, Salemba Empat, Jakarta.

Hartono, Jogiyanto. 2010. Teori Portofolio dan Analisis Investasi. BPFE. Yogyakarta.

Hurlock, 1999. Psikologi Perkembangan : Suatu Pendekatan Sepanjang Rentang Kehidupan. Edisi kelima (Terjemahan oleh Istiwidayanti). Jakarta: Erlangga.

Kusmawati. 2011. Pengaruh Motivasi Terhadap Minat Berinvestasi di Pasar
Modal dengan Pemahaman Investasi dan Usia sebagai Variabel Moderat. Jurnal Ekonomi dan Informasi Akuntansi (Jenius), Vol. 1 No. 2, Mei 2011. P: ISSN: 2302-514x. e:ISSN: 2303-1018.

Mumtaz, Fahmi. 2010. Investasi: Keinginan atau Kebutuhan?. Salemba Empat. Jakarta.

Oktiana Nur Sari. 2018. Pengaruh Pengetahuan, Keuntungan, Risiko dan Modal Minimal terhadap Minat Mahasiswa untuk Berinvestasi di Pasar Modal. Istitut Agama Islam Negeri Surakarta.

Tandio Timothius, A. A. G. P Widanaputra. 2016. Pengaruh Pelatihan Pasar Modal, Return, Persepsi Risiko, Gender, dan Kemajuan Teknologi pada Minat Berinvestasi Mahasiswa. E-Jurnal Akuntansi Universitas Udayana. Vol. 16 September 2016: 2316-2341.

Tengker, Victor S. G. Morasa Jenny. 2007. Pengaruh Motivasi Karir Terhadap Minat Mahasiswa Akuntansi Untuk Mengikuti Pendidikan Profesi Akuntansi (Ppak). Simposium Nasional Akuntansi. Manado.

Shum, P., Faig M. 2005. What Explains Households Stock Holdings? Journal of Banking and Finance, 30.

Sugiyono. 2018. Metode Penelitian Kuantitatif, Kualitatif, dan $R \& D$. Bandung: Alfabeta.

Stiggins, R.J. 1994. Student-Centered Classroom Assesment. Newyork: Macmillan College Publishing Company.

Yamishita, T. 2003. Owner-occupied housing and investment in stocks: An Empirical Test. Journal of Urban Economics, 53, 220-237.

Yuwono, R.S. 2011. Pengaruh Karakteristik Investor Terhadap Besaran Minat Investasi Saham di Pasar Modal. Jakarta: Universitas Indonesia.

www.idx.co.id

www.ksei.co.id www.logikabisnis.com 